\title{
QUANTIFICATION OF ENVIRONMENTAL ASSESSMENT PARAMETERS LEADING TO ECONOMICAL EVALUATION TECHNIQUE FOR CHOOSING THE TREATMENT METHOD FOR SMALL VILLAGES IN EGYPT.
}

\author{
Amro S. Kandil ${ }^{1}$, Mostafa Osman ${ }^{2}$, Medhat Abd Elmooty ${ }^{2}$, Walid Abd ElAzim ${ }^{2}$ and \\ Ahmed ElGendy ${ }^{3}$ \\ ${ }^{1}$ Construction Arab academy for Science \& Technology .Egypt \\ ${ }^{2}$ University of Alexandria Egypt \\ ${ }^{3}$ Prof. of sanitation Engrg American University in Cairo
}

\begin{abstract}
The sanitation situation in the remote Villages in the Delta Egypt is becoming not only a huge Environmental crises but also a crucial health problem. The problem lies in the rising of G.W.T due to the old used systems of disposal (bottomless cesspool "trench"), the waste water is mixing with the G.W.T and causing its rising to the extent that it floods the streets in some cases.

One of the solutions that was considered was stabilization ponds, another was Extended Aeration (activated sludge). As new concept the Japanese university introduced Down Hanging sponge as an experienced solution for the task.

For many years decision makers for sanitation in Egypt built their decision upon initial cost only, neglecting the other long term costs like running cost and operation and maintenance and other factors affecting the treatment processes.

Then when fundamentals of Value Engineering science were introduced, thinking began to change. Now after the development of Environmental Engineering science, other factors that may affect the decision making process, like sustainability, surrounding impact, the assessment, manipulation of environment.

Moreover other social factors were neglected like peoples habits and what effect that could have on them in daily life.

Their ability to manage every system in case of decentralization, the contribution of different stake holders that effects the management of every system especially in decentralization, those factors could be essential in any study.

This study focuses on these new parameters and to translate them into numerical values to help the decision makers to make a better judgment and to reach the most practical decision needed for sanitation and water treatment in Egypt.

The study of Environmental Impact Assessment (EIA) is becoming urgent and more relying on management techniques such as risk analysis, creating weight score matrices for different variables surrounding the Environment of the different treatment plants in each case depending on the location, the cultural habits of inhabitants, Socio economic impact assessment, Sociological impacts, Ethical considerations .
\end{abstract}

Keywords:

○ Stabilization Ponds (SPO)

$\circ$ Down Hanging Sponge (D.H.S).

$\circ$ Life cycle impact Assessment (LCIA).

$\circ$ Extended Aeration (E.A)

- Life Cycle Analysis (LCA).

$\circ$ Risk Assessment Analysis. 
QUANTIFICATION OF ENVIRONMENTAL ASSESSMENT PARAMETERS LEADING TO ECONOMICAL EVALUATION TECHNIQUE FOR CHOOSING THE TREATMENT METHOD FOR SMALL VILLAGES IN EGYPT.

$\circ$ Risk Assessment Management.

○Decentralization.

$\circ$ Life Cycle Inventory, Environmental Footprin.

$\circ$ Environmental social assessment (ESA).

$\circ$ Biological oxygen Demand (B.O.D).

$\circ$ Construction Management.

$\circ$ Output and Input Modeling.
○ Environmental Impact Assessment (EIA).

○ Clustering.

○ Social life-cycle assessment (S-LCA).

○ Village Council (CDA)

- Value Engineering.

- Sample Campaign Assessment.

\section{1- INTRODUCTION}

Mu'nicipal wastewater is the combination of liquid or water carried wastes originating in the sanitary conveniences of dwellings, commercial or industrial facilities and institutions, in addition to any groundwater, surface water and storm water that may be present. The quality of the treatment facility is one of the most country's difficulties which suffer from some anthropogenic insertion, including solid and liquid wastes from domestic wastewater of small rural areas. Such areas have the main source of pollutions and not included in the government's plans in near future for rehabilitation process or control (Metcalf, 2003).

For years Environmental Impact assessment (EIA) was qualitatively expressed much more than quantitatively figured. It was not until lately when slow progress in this manner was revealed, which shows need to add more effort specially from other brother tools. Value engineering science helps better optimization and more mature judgment which could help decision makers in their choice of path.

The pollution caused by the untreated waste water dumped into the Egyptian lakes and canals is a crucial problem. These can be shown properly when the following discussions is presented.

In rural Egypt There is 4627 villages and 27000 satellites. The present population in villages in Egypt is about 40 million .The Village average population is 15000capita.Range of population in each village is from 5000 to 50000 capita (according to data from the holding company).According to statements of the minster of infra-structure in 2012, 50\% of Egyptian population lack sanitation services and $80 \%$ of those live in rural areas and villages in Egypt. Sanitation level in Egyptian villages is 4\%.Typical system used is bottomless cesspool "trench". Trench emptying frequency: 3-4/month. The waste water (Grey water) may over flow the streets. The B.O.D reaches over $1000 \mathrm{mg} / \mathrm{lit}$ in some cases (especially when presence of animal manure).

The sanitation system usually consists of network, pump station, force main and treatment plant. Small units of treatment are the best solution for these villages, some examples that can be used: Imhoff tank. Extended aeration, Activated sludge, Aerated lagoons, Trickling filters, Rotating biological contactor (R.B.C), Oxidation ditch, Stabilization Ponds, Down Hanging Sponge (D.H.S).

Choosing the most suitable type for every case depends on a number of variables as Retention time, expected influent B.O.D, The land availability, Initial cost of construction, the surrounding neighboring environment, Environmental impact assessment, Social life-cycle assessment (S-LCA), Environmental social assessment (ESA), and the cost allowed per meter cube.

\section{2- Problem statement:}

The choice of the optimum solution faces huge challenges due to a lot of reasons which lead mostly to an unpractical solutions causing the average cost of cubic meter treated jumps over the optimum cost and sometimes even damaging the environment surroundings.

The problem lies in creating a scientific technique depends more on construction management science as a tool to generate designs to be compatible with environmental, economical, quality control requirements and take more variables (factors) into consideration.

Factors that are essential in modern life to understand more the impact of the decision making on the type of sanitation and water treatment technique that has on people's lives. Social 
QUANTIFICATION OF ENVIRONMENTAL ASSESSMENT PARAMETERS LEADING TO ECONOMICAL EVALUATION TECHNIQUE FOR CHOOSING THE TREATMENT METHOD FOR SMALL VILLAGES IN EGYPT.

effects that depends on peoples habits, especially the uniqueness of the Egyptian environment after studying those habits closely and what differentiate them from others.

The effect on stake holders and how they contribute in their community, is another accessory that need to be studied closely, like the fluency of understanding the proposed system by the village council (CDA) and the management of it in future.

That is if one must admit that decentralization is the future of managing the infrastructure, this fact became reality in the modern world now.

Other factors also is needed to be introduced like sustainability and environmental impact assessment, reuse of water and other waste like sludge reuse and treatment, all this data must be collected either by surveying or by other means of analysis to reach the right verdict .

\section{3- Objectives:}

Three techniques will be chosen for comparison: Stabilization Ponds, Extended Aeration and Down Hanging Sponge (D.H.S). Creating a score matrix technique to help the traditional value engineering study to be related more to the EIA study. And adding new parameters such as life cycle LCA to be scored and weighted hence valued.

\section{4 - Methodology:}

Applying Construction Management science technique mainly depending on ideas of Value engineering as a tool of comparison to create a proper economical evaluation process for every technique.

Based on mathematical equations, statistics, studying environment, through comparative analysis of existing different case studies hence creating philosophy of the technical choice.

This could be done by producing mathematical equations to simulate the variables that are not added to the usual value engineering studies.

Environmental assessment and the sustainability of the project and other variables will be scored in defined figures through a special score matrix technique.

Using sampling and other means of definition to reach the comparative analysis needed to choose the best treatment technique required for every case.

\section{5 - Benefits of research:}

Decreasing the pollution of drained water and creating a solution for waste water treatment for small abandoned villages, preserving health of people in these villages. Hence when reaching the right decision it Leads to increasing the agriculture area. Then preserving health of people in these villages, and the environment.

Help decision makers in deciding which type of treatment suitable in every case, creating a national technique for mass production of treatment for the Delta overall sanitation policy that can help the evaluation, estimation and then better sustainable management for treatment of waste water in Egypt.

\section{6- Tools to be added to the present traditional V.E technique:}

The problem is that new parameters which was not included in the original version of the traditional V.E study such as:

1- Life cycle analysis.

2- Life cycle impact assessment.

3- Life cycle inventory, Environmental footprint.

4- Risk assessment.

5- Risk assessment management.

6- Sample campaign assessment.

7- Output and input modeling.

Adding to the above the typical EIA factors that is significant in any study such as mitigation, impact and future impact on the Environment, base line, alternatives and public participation (V. Ratna Reddy · Mathew Kurian 2015). 
QUANTIFICATION OF ENVIRONMENTAL ASSESSMENT PARAMETERS LEADING TO ECONOMICAL EVALUATION TECHNIQUE FOR CHOOSING THE TREATMENT METHOD FOR SMALL VILLAGES IN EGYPT.

\section{7- RESULTS:}

Waste water technique (cases study):Demonstrating the New parameters needed to be added to the present V.E study in a case study of 3 nominated techniques are SPO, E.A, D.H.S: Introducing the 3 alternatives:-

Case 1 Stabilization ponds:

A village was chosen from the heart of the country side of the Delta in Egypt, El Quleaa, a SPO is constructed their by researcher serving a designed 5000capita and of discharge of $500 \mathrm{~m} 3$ /day, as a disposal rate of 100 lit/capita/D.

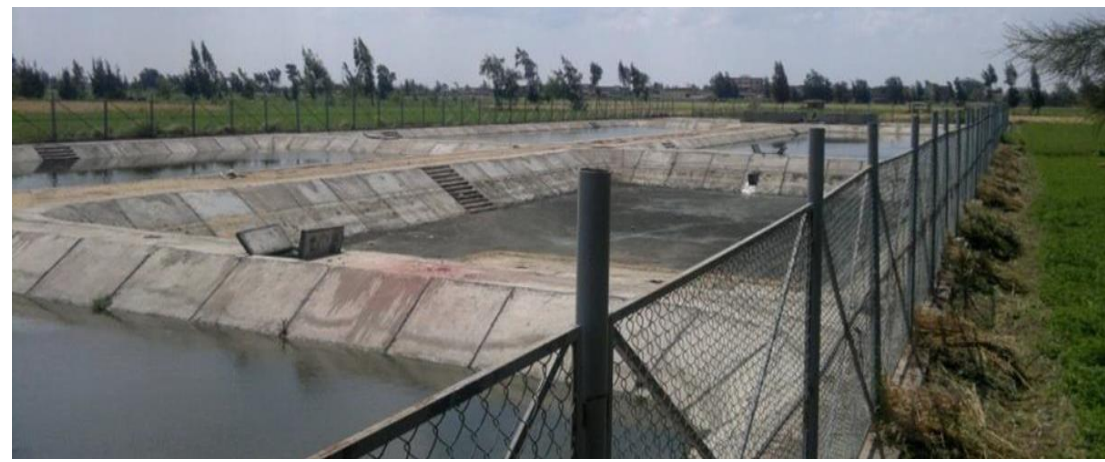

Figure 1. Quleaa SPO plant at Kafr EIShiekh , Egypt with 500m3/d capacity.

Design data for future requirements for Quleaa village of kafr ElShiekh:

- Present population - 1600 capita.

- At year 2026 expected population - 2310 capita.

- At year 2046 expected population - 3330 capita.

- Present discharge $-173 \mathrm{~m}^{3} /$ day.

- Expected B.O.D (Present influent quality) - $535 \mathrm{mg} / \mathrm{lit}$.

- Plant Desioned for servino 500 n canita and $500 \mathrm{~m}^{3} / \mathrm{dav}$
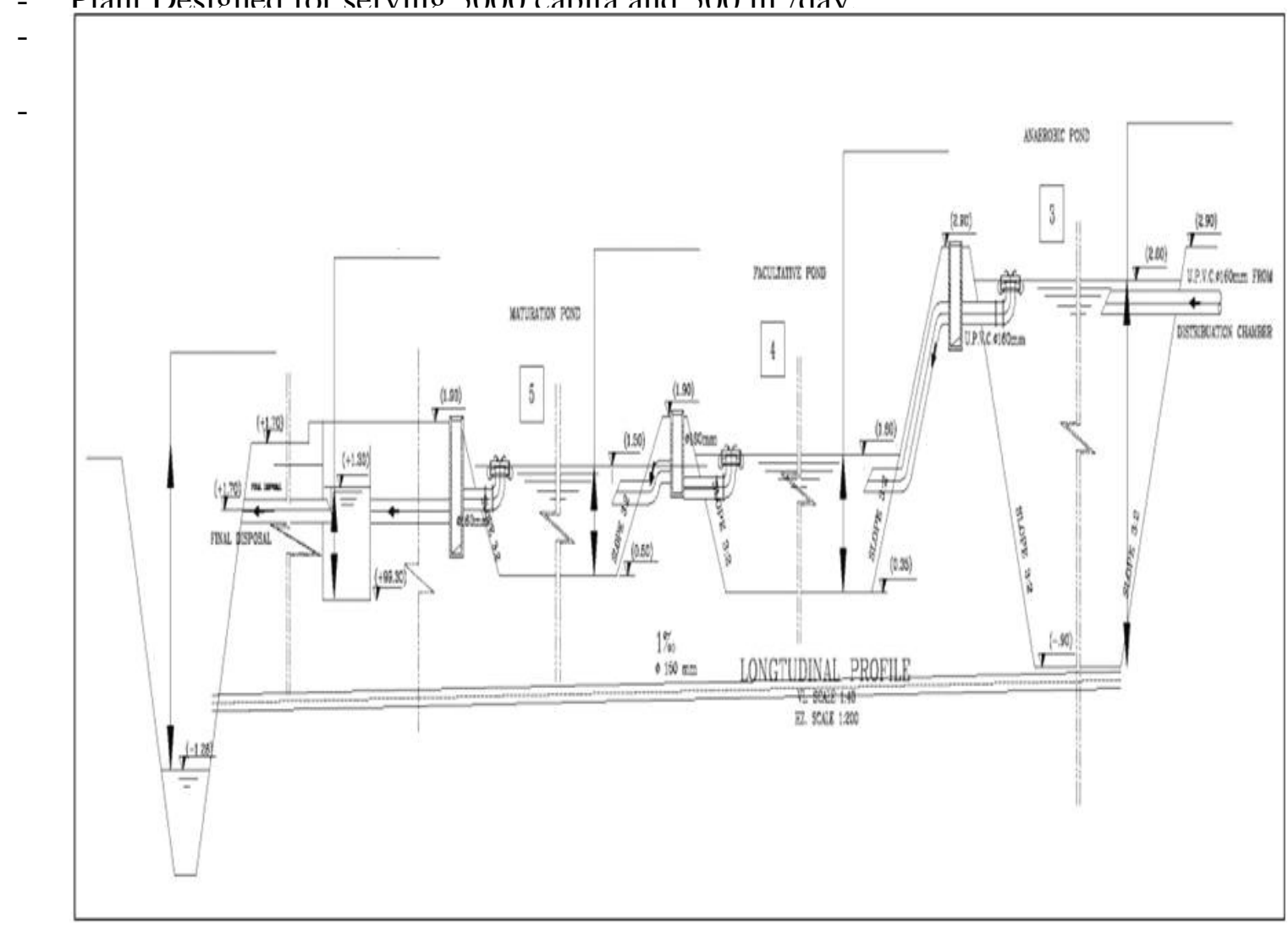

Figure 2. longitudinal cross-section in existing SPO W.W.T.P at Kafr ElShiekh Egypt 
QUANTIFICATION OF ENVIRONMENTAL ASSESSMENT PARAMETERS LEADING TO ECONOMICAL EVALUATION TECHNIQUE FOR CHOOSING THE TREATMENT METHOD FOR SMALL VILLAGES IN EGYPT.

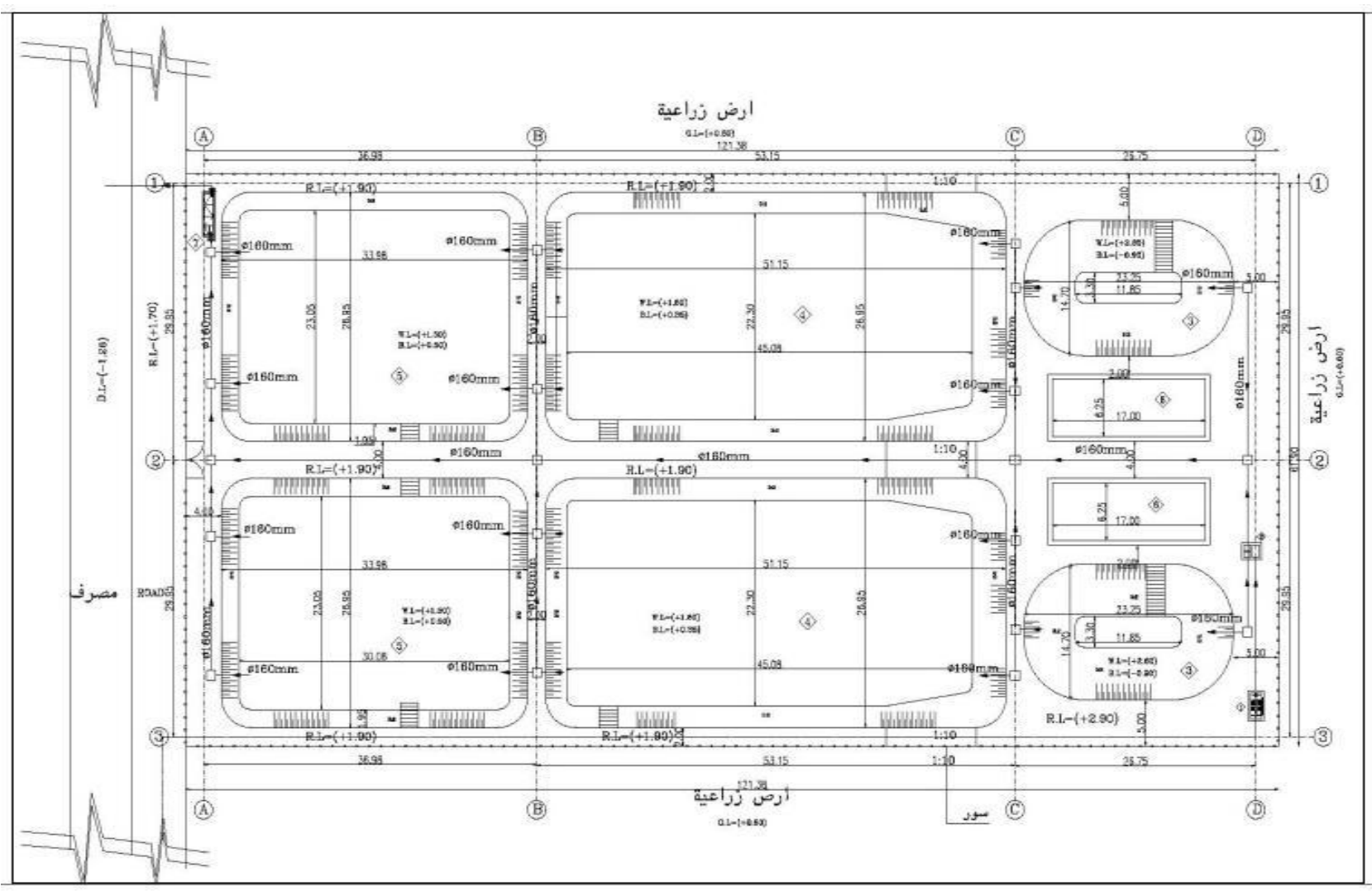

Figure 3. : Arrangement of Quleaa existing S.P.O in KafrElSheikh (executed by researcher) (Holding archives).

\section{Case 2 Extended Aeration:}

A plant (executed by researcher) was chosen from a resort in the red sea operating all year time and its effluent is reused unrestrictedly to irrigate a golf coarse.

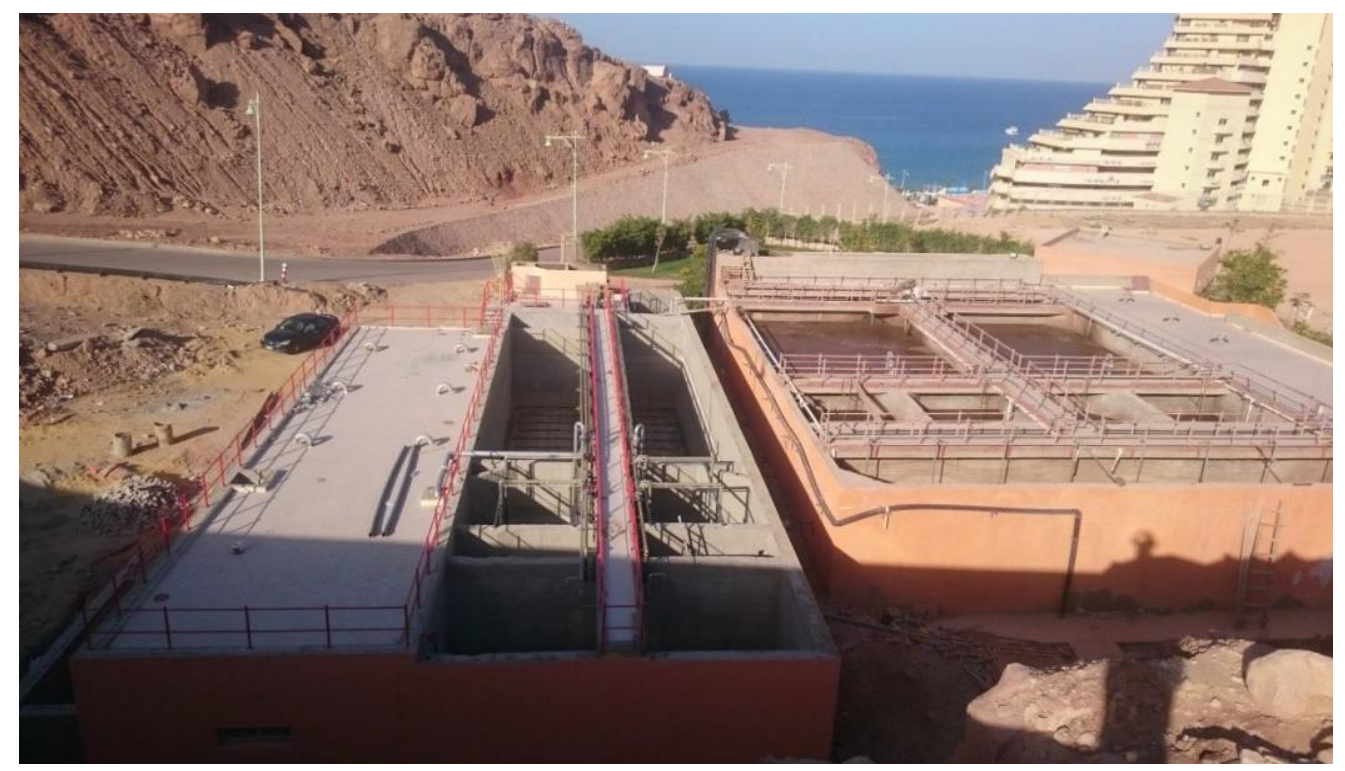

Figure 4. : Extended W.W.T.P at red sea resort \& its expansion (executed by researcher). 
QUANTIFICATION OF ENVIRONMENTAL ASSESSMENT PARAMETERS LEADING TO ECONOMICAL EVALUATION TECHNIQUE FOR CHOOSING THE TREATMENT METHOD FOR SMALL VILLAGES IN EGYPT.

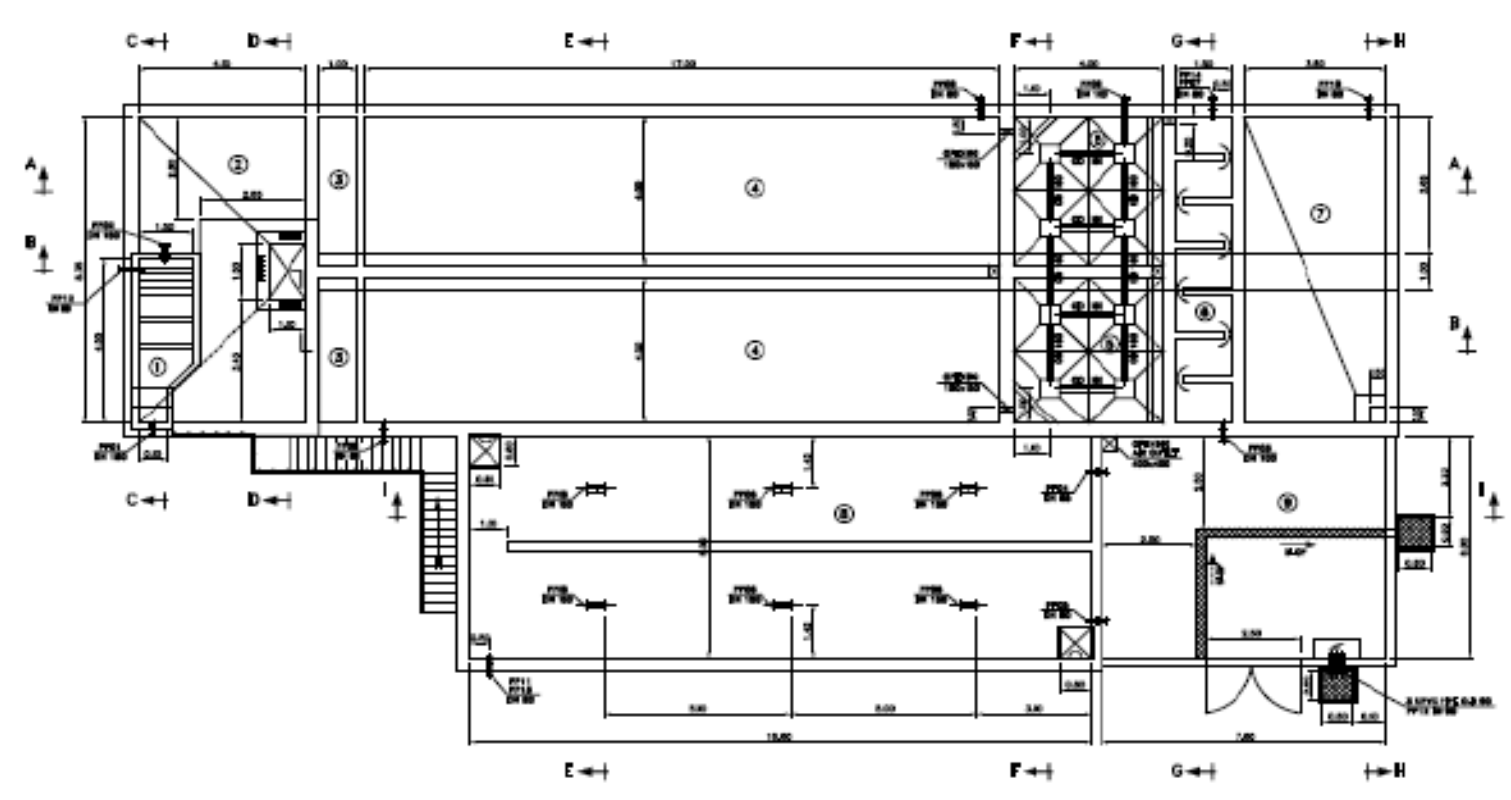

Figure 5. Plan of existing Extended Aeration W.W.T.P at red sea resort (executed by researcher).

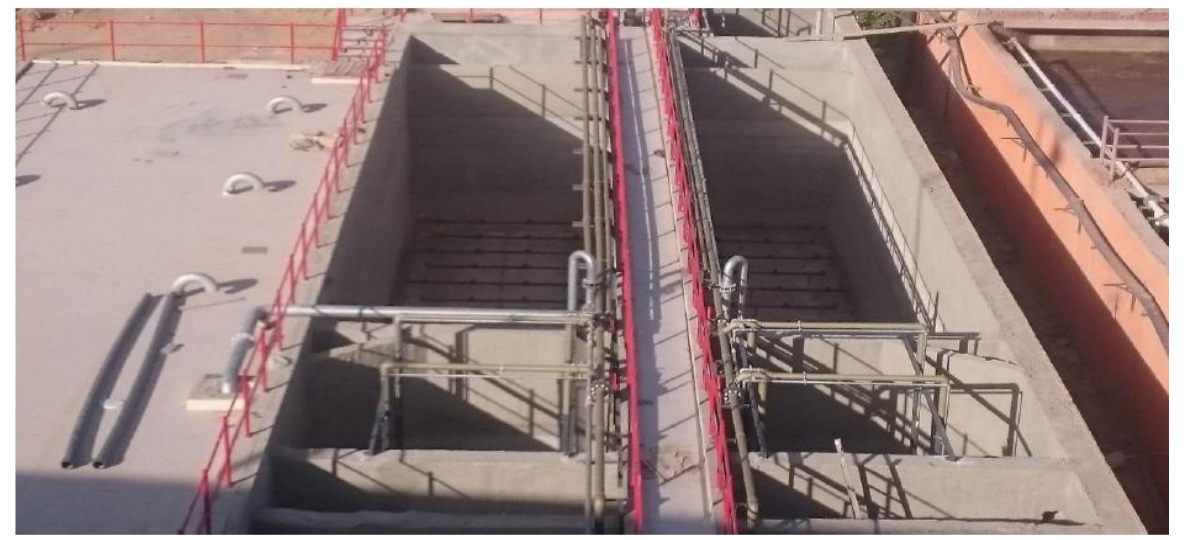

Figure 6. : Extended aeration air nozzles at W.W.T.P expansion (executed by researcher).

Table 1. Waste water parameters (influent) for extended aeration plant.

\begin{tabular}{|l|c|}
\hline \multicolumn{1}{|c|}{ Wastewater Parameter } & Values \\
\hline Average daily Flow $\left(\mathrm{m}^{3} /\right.$ day) & 500 \\
\hline Number of streams & 2 \\
\hline Average flow $\left(\mathrm{m}^{3} / \mathrm{hr}\right)$ & 20.84 \\
\hline Peak hourly flow $\left(\mathrm{m}^{3} / \mathrm{hr}\right)$ & 62.52 \\
\hline Inlet BOD $(\mathrm{mg} / \mathrm{L})$ & 350 \\
\hline Inlet BOD Load $(\mathrm{kg} / \mathrm{d})$ & 170 \\
\hline Inlet SS $(\mathrm{mg} / \mathrm{L})$ & 400 \\
\hline Inlet SS $(\mathrm{kg} / \mathrm{d})$ & 195 \\
\hline Water temperature $\left[{ }^{\circ} \mathrm{C}\right]$ & Min. 20 \\
\hline PH & $6-9$ \\
\hline
\end{tabular}


QUANTIFICATION OF ENVIRONMENTAL ASSESSMENT PARAMETERS LEADING TO ECONOMICAL EVALUATION TECHNIQUE FOR CHOOSING THE TREATMENT METHOD FOR SMALL VILLAGES IN EGYPT.

\section{TREATED EFFLUENT QUALITY REQUESTED}

According to Law No. 93of 1962, decree $44 / 2000$ concerning the reuse of treated municipal wastewater in irrigation

\begin{tabular}{|c|c|}
\hline Parameter & $\begin{array}{l}\text { Maximum limits of Criteria and } \\
\text { Specifications (mg/Lit.-unless } \\
\text { otherwise indicated.) } \\
\text { Categ A }\end{array}$ \\
\hline $\mathrm{PH}$ & $6-9$ \\
\hline Biochemical Oxygen Demand (BOD) & 20 \\
\hline Total Suspended materials & 20 \\
\hline Estimated Fecal Coliform Count in 100 \\
$\mathrm{cm} 3$
\end{tabular}

Based on composite weekly average sampling and monthly analysis results

\section{TREATED EFFLUENT QUALITY GUARRANTEE}

Based on the proposed raw influent characteristics, we guarantee the performance of the plant to achieve effluent standard as below:

\begin{tabular}{|c|c|}
\hline Parameter & Limits \\
\hline \multicolumn{2}{|c|}{ After secondary treatment } \\
\hline $\mathrm{BOD}_{5}$ & $\leq 30 \mathrm{mg} / \mathrm{L}$ \\
\hline S.S & $\leq 30 \mathrm{mg} / \mathrm{L}$ \\
\hline \multicolumn{2}{|l|}{ After Tertiary treatment } \\
\hline $\mathrm{BOD}_{5}$ & $\leq 10 \mathrm{mg} / \mathrm{L}$ \\
\hline S.S & $\leq 10 \mathrm{mg} / \mathrm{L}$ \\
\hline
\end{tabular}

The $3^{\text {rd }}$ alternative Case 3: D.H.S and 2 choices can be used one constructed at Borg Arab city executed by the Japanese University as pilot project or a plant not yet operational at Fayoum but the target of both is $500 \mathrm{~m} 3 /$ day and same parameters of the previous cases:

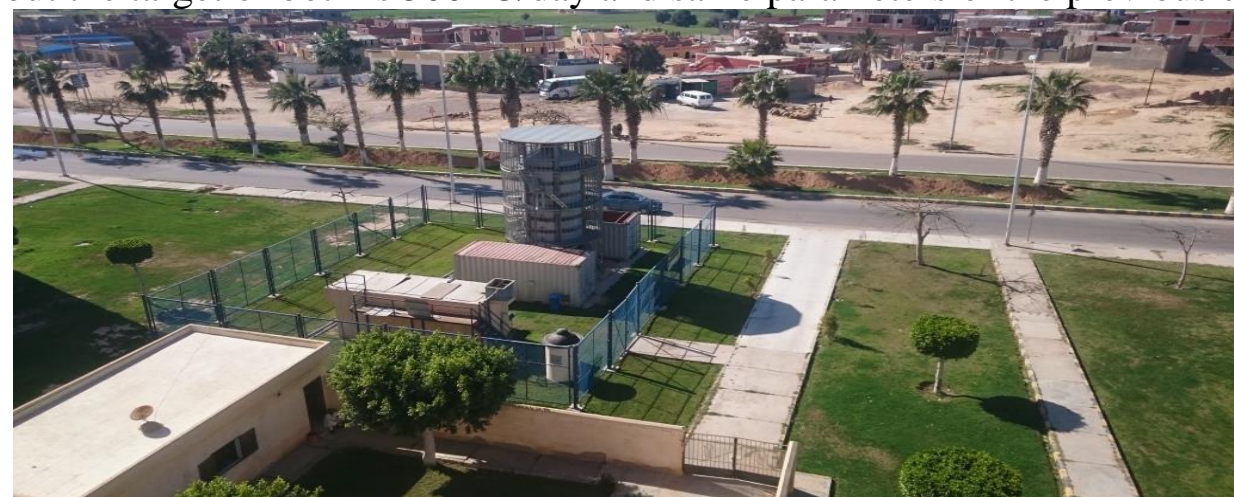

Figure 7. : D.H.S W.W.T.P at Borg ElArab executed by Tohoku University \& by E.JUST University. 
QUANTIFICATION OF ENVIRONMENTAL ASSESSMENT PARAMETERS LEADING TO ECONOMICAL EVALUATION TECHNIQUE FOR CHOOSING THE TREATMENT METHOD FOR SMALL VILLAGES IN EGYPT.

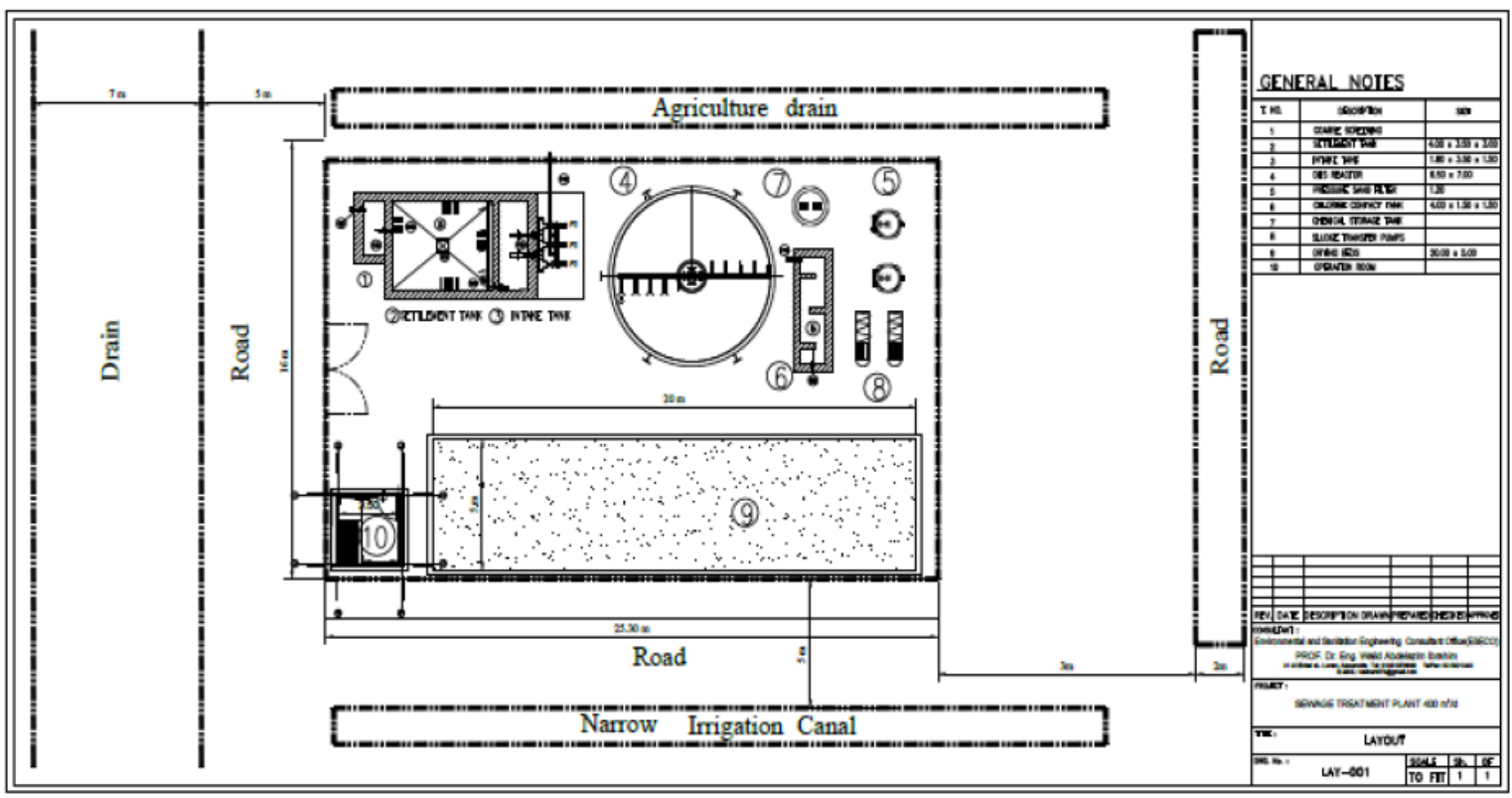

Figure 8. Layout of a D.H.S plant of $500 \mathrm{~m}^{3}$ /day at Egypt (Alex. Uni. service center).

Table 2. Cost Summary for S.P.O, D.H.S and E.A Plants.

\begin{tabular}{|c|c|c|c|c|}
\hline & Cost Item & $\begin{array}{l}\text { Down Hanging } \\
\text { Sponge } \\
\text { D.H.S }\end{array}$ & \begin{tabular}{|l|} 
Complete-Mix \\
Extended Aeration
\end{tabular} & $\begin{array}{l}\text { Stabilization } \\
\text { ponds }\end{array}$ \\
\hline \multicolumn{2}{|c|}{$\begin{array}{l}\text { (1) Unit process construction cost }+ \\
\text { equipment cost } \\
\text { (L.E) }\end{array}$} & $2,500,900$ & $3,497,000$ & $2,130,000$ \\
\hline \multirow{5}{*}{$\begin{array}{l}\text { (2) Other cost } \\
\text { (L.E) }\end{array}$} & (a) Other construction cost ${ }^{*}$ & 88,915 & 88,915 & 88,915 \\
\hline & (b) Non-construction cost ${ }^{* *}$ & 73,553 & 96,458 & 93,085 \\
\hline & (c) Land cost & 60,000 & 100,000 & $1,440,000$ \\
\hline & $\begin{array}{l}\text { (d) Interest during } \\
\text { Construction } i=15 \%\end{array}$ & $408,505.2$ & $567,355.9$ & $1,130,155.9$ \\
\hline & (e) Total $(a+b+c+d)$ & $3,131,873.2$ & $4,349,728.9$ & $4,882,155.9$ \\
\hline \multicolumn{2}{|c|}{ (3) Profit and overhead 15\% } & $469,780.98$ & 652,459 & $732,323.4$ \\
\hline \multicolumn{2}{|c|}{$\begin{array}{l}\text { (4) Total construction cost }=1+2-a+3 \\
\text { (L.E) }\end{array}$} & $3,059,595.98$ & $4,238,374$ & $2,951,238.4$ \\
\hline \multicolumn{2}{|c|}{$\begin{array}{l}\text { (5) Project cost }=1+2+3 \\
\text { (L.E) }\end{array}$} & $6,102,554.1$ & $8,499,187.9$ & $7,744,479.3$ \\
\hline \multicolumn{2}{|c|}{$\begin{array}{c}\text { (6) Annual O \& M labor cost } \\
\text { (L.E/year) }\end{array}$} & 14000 & 20,000 & 9000 \\
\hline \multicolumn{2}{|c|}{$\begin{array}{l}\text { (7) Annual material, chemical and energy } \\
\text { cost } \\
\text { (L.E/year) }\end{array}$} & 10,000 & 25,000 & 5,000 \\
\hline \multicolumn{2}{|c|}{$\begin{array}{l}\text { (8) Total annual O \& M cost }=6+7 \\
\text { (L.E/year) }\end{array}$} & 24,000 & 45,000 & 14,000 \\
\hline \multicolumn{2}{|c|}{$\begin{array}{l}\text { (9) Present worth } \\
\text { (L.E) }\end{array}$} & & & \\
\hline \multicolumn{2}{|c|}{$\begin{array}{l}\text { (10) Annualized project cost } \\
\text { (L.E/year) }\end{array}$} & $203,418.47$ & 283,806 & $258,149.3$ \\
\hline \multicolumn{2}{|c|}{$\begin{array}{l}\text { (11) Annualized project cost }+ \text { Annual } O \\
\& \mathrm{M} \text { cost }=10+8 \\
\text { (L.E/year) }\end{array}$} & $227,418.47$ & $\mathbf{3 2 8 , 8 0 6}$ & $272,149.3$ \\
\hline (12) Cost $/ \mathrm{m}^{3}$ & (L.E / m $3 / \mathrm{d})$ & $\begin{array}{c}454.8 \\
1.24 \mathrm{L.E} / \mathrm{m3} / \mathrm{d}\end{array}$ & $\begin{array}{c}657.6 \\
1.8 \mathrm{L.E} / \mathrm{m3} / \mathrm{d}\end{array}$ & $\begin{array}{c}544.3 \\
1.49 \text { L.E } / \mathrm{m3} / \mathrm{d}\end{array}$ \\
\hline
\end{tabular}

pipinger construction cost includes costs of mobilization, site preparation, site electrical, yard

$* *$ ping, instrumentation and control, and lab and administration buildings. cost, contingency, and miscellaneous cost.

$* * * \quad$ Annualized project cost $=$ project cost $\mathrm{x}$ CRF. For $\mathrm{i}=8 \%$ and planning period $=30$ years,

$\mathrm{CRF}=0.089$

**** Cost $/ \mathrm{m}^{3}\left(\mathrm{~L} . \mathrm{E} / \mathrm{m}^{3}\right)=$ [annualized project cost + annual O \& $\mathrm{M}$ cost] $\mathrm{SR} /$ year $\div$ [average design flow, $\mathrm{m}^{3} /$ day $\mathrm{x} 365$ day 
QUANTIFICATION OF ENVIRONMENTAL ASSESSMENT PARAMETERS LEADING TO ECONOMICAL EVALUATION TECHNIQUE FOR CHOOSING THE TREATMENT METHOD FOR SMALL VILLAGES IN EGYPT.

Table 4. Criteria weighting score:

\begin{tabular}{|l|l|l|}
\hline Criteria & Weight & Raw score \\
\hline Initial cost & 10 & 16 \\
\hline Maintenance cost & 5 & 8 \\
\hline Performance & 8 & 12 \\
\hline Operation cost & 2 & 3 \\
\hline Land saving & 8 & 12 \\
\hline Replacement cost & 2 & 3 \\
\hline control & 3 & 5 \\
\hline
\end{tabular}

Table 5. Score evaluation:

\begin{tabular}{|c|c|c|c|c|c|c|c|c|c|c|c|c|c|c|c|c|}
\hline & \multicolumn{2}{|c|}{ Initial cost } & \multicolumn{2}{|c|}{$\begin{array}{l}\text { Maintenance } \\
\text { cost }\end{array}$} & \multicolumn{2}{|c|}{$\begin{array}{l}\text { Perform } \\
\text { ance }\end{array}$} & \multicolumn{2}{|c|}{$\begin{array}{l}\text { Operation } \\
\text { cost }\end{array}$} & \multicolumn{2}{|c|}{$\begin{array}{l}\text { Land } \\
\text { saving }\end{array}$} & \multicolumn{2}{|c|}{$\begin{array}{l}\text { Replace } \\
\text { ment cost }\end{array}$} & \multicolumn{2}{|c|}{ control } & \multicolumn{2}{|c|}{ sustainability } \\
\hline $\begin{array}{l}\text { Weight of } \\
\text { importance }\end{array}$ & \multicolumn{2}{|l|}{$\mathbf{a}$} & \multicolumn{2}{|l|}{ b } & \multicolumn{2}{|l|}{ c } & \multicolumn{2}{|l|}{ d } & \multicolumn{2}{|l|}{ e } & \multicolumn{2}{|l|}{ f } & \multicolumn{2}{|l|}{$\mathbf{g}$} & \multicolumn{2}{|l|}{$\mathbf{h}$} \\
\hline$(0.10)$ & \multicolumn{2}{|l|}{10} & \multicolumn{2}{|l|}{5} & \multicolumn{2}{|l|}{8} & \multicolumn{2}{|l|}{2} & \multicolumn{2}{|l|}{8} & \multicolumn{2}{|l|}{2} & \multicolumn{2}{|l|}{3} & \multicolumn{2}{|l|}{3} \\
\hline D.H.S Alt 2 & 40 & 4 & 15 & 3 & 32 & 4 & 8 & 4 & 40 & 5 & 6 & 3 & 6 & 2 & 12 & 4 \\
\hline SPO Alt 1 & 33 & 2 & 15 & 3 & 16 & 2 & 10 & 5 & 16 & 1 & 6 & 3 & 9 & 3 & 15 & 5 \\
\hline E.A Alt 3 & 28 & 3 & 25 & 5 & 32 & 4 & 4 & 2 & 24 & 3 & 6 & 3 & 15 & 5 & 6 & 2 \\
\hline
\end{tabular}

\begin{tabular}{|c|c|c|c|c|c|c|c|c|c|c|c|c|c|c|}
\hline & \multicolumn{2}{|c|}{$\begin{array}{l}\text { Possibility of } \\
\text { alternatives }\end{array}$} & \multicolumn{2}{|c|}{$\begin{array}{l}\text { Environmental } \\
\text { manipulation }\end{array}$} & \multicolumn{2}{|c|}{ impact } & \multicolumn{2}{|c|}{$\begin{array}{l}\text { Land } \\
\text { value }\end{array}$} & \multicolumn{2}{|c|}{$\begin{array}{l}\text { Mitigation } \\
\text { best }\end{array}$} & \multicolumn{2}{|c|}{$\begin{array}{l}\text { Monitoring } \\
\text { \& control }\end{array}$} & $\begin{array}{l}\text { Public } \\
\text { participation }\end{array}$ & Total \\
\hline $\begin{array}{l}\text { Weight } \\
\text { of } \\
\text { importa } \\
\text { nce }\end{array}$ & \multicolumn{2}{|l|}{ I } & \multicolumn{2}{|l|}{$\mathbf{j}$} & \multicolumn{2}{|l|}{ k } & \multicolumn{2}{|l|}{1} & \multicolumn{2}{|c|}{ m } & \multicolumn{2}{|l|}{$\mathbf{n}$} & o & \\
\hline$(0.10)$ & \multicolumn{2}{|l|}{0.5} & \multicolumn{2}{|l|}{1} & \multicolumn{2}{|l|}{0.5} & \multicolumn{2}{|l|}{3} & \multicolumn{2}{|l|}{1} & \multicolumn{2}{|l|}{3} & 2 & \\
\hline Alt 2 & 2 & 4 & 4 & 4 & 2 & 4 & 15 & 5 & 3 & 4 & 6 & 2 & 8 & \\
\hline Alt 1 & 0.5 & 1 & 1 & 1 & 0.5 & 1 & 3 & 1 & 1 & 1 & 6 & 2 & 6 & \\
\hline Alt 3 & 1 & 2 & 3 & 3 & 1 & 2 & 9 & 3 & 3 & 3 & 9 & 3 & 4 & \\
\hline
\end{tabular}

\begin{tabular}{|c|c|c|c|c|c|c|c|c|c|c|c|c|c|c|}
\hline & \multicolumn{2}{|c|}{$\begin{array}{l}\text { Possibility of } \\
\text { expansion }\end{array}$} & \multicolumn{2}{|c|}{$\begin{array}{l}\text { Comparative } \\
\text { risk } \\
\text { assessment } \\
\text { (CRASS) }\end{array}$} & \multicolumn{2}{|c|}{$\begin{array}{l}\text { Comparative } \\
\text { risk } \\
\text { management } \\
\text { (CRM) }\end{array}$} & \multicolumn{2}{|c|}{$\begin{array}{l}\text { Sample } \\
\text { campaign } \\
\text { analysis }\end{array}$} & \multicolumn{2}{|c|}{$\begin{array}{l}\text { Life cycle } \\
\text { analysis }\end{array}$} & \multicolumn{2}{|c|}{$\begin{array}{l}\text { Environmental } \\
\text { footprint }\end{array}$} & $\begin{array}{l}\text { Environmental } \\
\text { input output } \\
\text { modeling }\end{array}$ & Total \\
\hline $\begin{array}{l}\text { Weight } \\
\text { of } \\
\text { import } \\
\text { ance } \\
\end{array}$ & \multicolumn{2}{|l|}{$\mathbf{p}$} & \multicolumn{2}{|l|}{$\mathbf{S}$} & \multicolumn{2}{|l|}{$\mathrm{t}$} & \multicolumn{2}{|l|}{$\mathbf{u}$} & \multicolumn{2}{|l|}{$\mathbf{X}$} & \multicolumn{2}{|l|}{$\mathbf{y}$} & $\mathbf{Z}$ & \\
\hline$(0.10)$ & \multicolumn{2}{|l|}{3} & \multicolumn{2}{|l|}{2} & \multicolumn{2}{|l|}{1} & \multicolumn{2}{|l|}{2} & \multicolumn{2}{|l|}{2} & \multicolumn{2}{|l|}{1} & 1 & \\
\hline Alt 2 & 15 & 5 & 6 & 3 & 4 & 4 & 6 & 3 & 6 & 3 & 2 & 2 & 2 & 240 \\
\hline Alt 1 & 3 & 1 & 4 & 2 & 2 & 2 & 4 & 2 & 6 & 3 & 3 & 3 & 2 & 160 \\
\hline Alt 3 & 12 & 4 & 8 & 4 & 5 & 5 & 8 & 4 & 6 & 3 & 2 & 2 & 2 & 213 \\
\hline
\end{tabular}

Note: 5- excellent 4- very good 3- good 2- fair 1- poor 
QUANTIFICATION OF ENVIRONMENTAL ASSESSMENT PARAMETERS LEADING TO ECONOMICAL EVALUATION TECHNIQUE FOR CHOOSING THE TREATMENT METHOD FOR SMALL VILLAGES IN EGYPT.

\section{8- DISCUSSION:}

From the above it is demonstrated that using the suggested theory that the choice of D.H.S scored best in the direct cost analysis per $\mathrm{m} 3 / \mathrm{d}$ than the other 2 solutions since it costs 1.24L.E/m3/day for D.H.S while for SPO and E.A it costs $1.49 \mathrm{~L} . \mathrm{E} / \mathrm{m} 3 /$ day and $1.8 \mathrm{~L} . \mathrm{E} / \mathrm{m} 3 /$ day respectively.

Of course all the figures above are taken from field previous experiences and scores and weights should be produced through an online survey for 30 different experts that should include professors of sanitation, sanitation water experts and government officials in the water companies and members of CDA all distributed upon their experience.

Applying the new parameters scoring it was also the D.H.S scored 240 points while SPO and E.A scored 160 and 213 points respectively.

It must be noted for the record that the parameter of land cost and land value had an essential role in the score since land cost is the cost of land in the present worth but land value is the change occurred on value due to impact of the change of use from agriculture to a W.T.P and it is evaluated by the rent of land in the period of project which is 30 years.

Habits of the residents if they raise animals or they are mostly in governmental jobs like case of Quleaa has also significant effect on choice since animal manure can be a bit hard in treatment in case of SPO as experience proves then maybe Extended aeration can be a better choice.

Also type management system to be used such as decentralization or the combination of several villages in a cluster, those factors can be have relatively impact on weight and score, which in this case Extended Aeration can be if valued a better choice.

\section{9- CONCLUSION \& RECOMMENDATIONS: \\ 9.1 CONCLUSIONS:}

Throughout the course of history the evolution of techniques of waste water treatment plants and the rising of environmental science came up the need of new evaluation techniques for re modeling the traditional techniques of evaluation.

This study reached the need for new parameters needs to be introduced concerning the environment to the traditional value engineering techniques.

Those parameters were introduced before by others such as life cycle analysis, life cycle impact assessment and risk assessment management added to that the general aspects of the environmental impact assessment usual parameters.

The aim of the study a way to find a rule of thumb to score those new parameters and weight them compared to the old traditional parameters of the usual value engineering study.

First a general briefing for the sanitation process was given ended by the introducing of the three different techniques that will be used later in the case study to proof the above mentioned theory.

Those three techniques are the Stabilization ponds, the Down Hanging Sponge and the Extended Aeration technique demonstrated by three different case studies from the Egyptian environment mostly executed by researcher.

Then the approach of modification to be done to the usual value engineering study along by defining the new parameters to quantify the EIA such as LCA, LCIA, Risk management was done.

And the study concentrated on only two sides of evaluation throughout the life cycle of product, the land value and the efficiency of every technique.

After the new approach was practiced data survey was analyzed to reach the most technique available of quantification of EIA to reach the most suitable verdict for W.W.T.P for the small villages in Egypt.

Regarding the introduction of life cycle analysis as a factor of comparison along with the life cycle impact assessment and the risk assessment and the life cycle inventory, all those factors if considered in the land consumption and efficiency they fluctuate about equally between D.H.S and the E.A.

While they are very weak regarding the SPO but they there significance does not exceed $10 \%$ of the construction cost according to the weighing score matrix used in the assessment. 
QUANTIFICATION OF ENVIRONMENTAL ASSESSMENT PARAMETERS LEADING TO ECONOMICAL EVALUATION TECHNIQUE FOR CHOOSING THE TREATMENT METHOD FOR SMALL VILLAGES IN EGYPT.

\subsection{Recommendations:}

It is found after this study that the parameters can be increased according to evolution of environmental science that is rapidly in progress every day finding justification of progress due to our need to preservation of environment.

Also this study revealed that the DHS is in a lot of aspects in case of the Egyptian villages more than 5000 capita and less than 50000 capita more land preserving, Better in case of water reuse specially if unrestricted.

Moreover the D.H.S proved to be more economical than the other two options, the SPO and the E.A plants for this amount of discharge in capital cost but not in O\&M since the SPO is cheaper and more sustainable in this area.

Since its simple components for construction makes it more economical and also can be pre cast built in a mass building facility and installed at site which makes it a convenient solution on the national scale to preserve constant quality fabric. And to guarantee automatically a constant degree of performance of treatment.

Other solutions as Zeco treatment plant can be also of the same use since it is the same idea of treatment with sponge media.

In case of public participation in O\&M the D.H.S is not the simplest but in between both techniques but as mentioned before since it can be manufactured on massive scale also training \& awareness can be also done on a national scale as to train several amount of users in the same training facility.

This also guarantee a significant standard of operation and degree of knowledge to the environmental challenges that face those villages and create a mass awareness and general knowledge.

The only problem found for this system is that in case of seasonal operation when the discharge is fluctuating from high to low discharge.

Then the bacteria needs stimulating and this process has to be done on a professional level that cannot easily provided in the available O\&M local contractors.

Then in this case if land conservation is an essential factor then the E.A is the best choice other than that then the SPO can be taken into consideration.

\section{REFERENCES}

2. Economic and Social Commission for Western Asia: "Wastewater Treatment Technologies", http://www.escwa.un.org/information/publications/edit/upload/sdpd-03-6.pdf

3. Metcalf \& Eddy:Wastewater Engineering Treatment and Reuse Fourth Edition, 2003

4. Mogens Henze, Poul Harremoes, Jes La Cour Jansen, Eric Arvin: "Wastewater Treatment Biological and Chemical Processes" Three Edition, 2002.

5. Syed R. Qasim: "Wastewater Treatment plants", 1999.

6. Medhat Abd El Moty: PHD thesis "Improving the denitrification potential in biological wastewater treatment by dosing carbon from sludge hydrolysis", 1997.

7. PIPELINE - fall 1997; Vol. 8, No. 4: "Basic Wastewater Characteristics". http://www.nrcce.wvu.edu/programs/nesc/docs/SFPLNL11.pdf

8. Ronald L. Droste: "Theory and Practice of Water and Wastewater Treatment", 1997.

9. Metcalf \& Eddy:Wastewater Engineering Treatment and Reuse Three Edition, 1991.

10. J. B. White: "Wastewater Engineering", 1978.

11. Linvil G. Rich: "Unit operation of Sanitary Engineering", 1961.

12. $\square \square$ Miguel Pena Varon and Mara Duncan" Waste Stabilization ponds" University of Leeds, UK. July 2004

13. Droste,L. Ronald " Theory and Practice of Water and Wastewater Treatment"

14. Shilton, Andy and Harrison Jill "Guidelines for the hydraulic design of Waste Stabilization Ponds" 2003.

15. Kayombo, S. Mbwette, T.S.A. Katima, J.H.Y.Ladegaard, N. and Jorgensen, S.E. "Waste Stabilization Ponds and Constructed Wetlands - Design manual ". 2000 
QUANTIFICATION OF ENVIRONMENTAL ASSESSMENT PARAMETERS LEADING TO ECONOMICAL EVALUATION TECHNIQUE FOR CHOOSING THE TREATMENT METHOD FOR SMALL VILLAGES IN EGYPT.

16. Arther, J.P. "Notes on the Design and Operation of Waste Stabilization Ponds in Warm Climates of Developing Countries World Bank Technical Paper Number 7, 1990

17. Life-cycle Cost Approach for Management of Environmental Resources a Primer V. Ratna Reddy · Mathew Kurian Reza Ardakanian 2015.

18. Davis SC, Anderson T, Kristina J, DeLucia EH (2008) Life-cycle analysis and the ecology of biofuels. Trends Plant Sci14(3).doi:10.1016/j.tplants.2008.12.006. Retrieved April 10, 2014,from http://www.life.illinois.edu/delucia/Publications/Davis\%20Life\%20Cycle.pdf.

19. Harris S, Narayanaswamy V (2009) A literature review of life cycle assessment in agriculture. RIRDC Publication No 09/029, RIRDC Project No PRJ-002940, Rural Industries Research and Development Corporation, Australian Government. Retrieved April 10, 2014, from https://rirdc.infoservices.com.au/downloads/09-029

20. Hoff H (2011) Understanding the nexus. Background Paper for the Bonn 2011 Conference: The Water, Energy and Food Security Nexus. Stockholm Environment Institute, Stockholm. Retrieved April 10, 2014, from http://www.constructionindex.com/doccbwhollif.html.

21. Iraldo F, Testa F, Bartolozzi I (2014) An application of life cycle assessment (LCA) as a green marketing tool for agricultural products: the case of extra-virgin olive oil in Val di Cornia, Italy. J Environ Plann Manage 57(1):78-103. doi:10.1080/09640568.2012.735991.

22. Koehler A (2008) Water use in LCA: managing the planet's freshwater resources. Int J Life Cycle Assess 13:451-455. doi:10.1007/s11367-008-0028-6.

23. Koroneos CJ, Achillas CH, Moussiopoulos N, Nanaki EA (2013) Life cycle thinking in the use of natural resources. Open Environ Sci 7:1-6.

24. LNRMI et al (2014) Sustainable water and sanitation services: the life-cycle cost approach to planning and management. Earthscan Studies in Water Resource Management, Routledge. ISBN-10: 041582818X|ISBN-13: 978-0415828185.

25. UNEP (2012) Greening the economy through life cycle thinking. Retrieved April 10, 2014 ,from ttp://www.unep.fr/shared/publications/pdf/DTIx 1536xPAGreeningEconomythrough- LifeCycleThinking.pdf. 